\title{
EFEKTIVITAS PENGGUNAAN MEDIA GRAFIS UNTUK MENINGKATKAN HASIL BELAJAR IPA
}

\author{
MARTUA FERRY SIBURIAN \\ ferrysiburian79@gmail.com
}

\section{JUPRIADI}

Program Studi Pendidikan Biologi

Fakultas Teknik, Matematika dan Ilmu Pengetahuan Alam

Universitas Indraprasta PGRI

\begin{abstract}
Abstrak. Tujuan dari penelitian ini adalah untuk mengetahui efektivitas penggunaan media grafis dalam meningkatkan hasil belajar IPA kelas VII SMP Negeri 209 Jakarta. Metode penelitian yang digunakan dalam penelitian ini adalah pendekatan kualitatif dengan teknik penelitian tindakan kelas, yaitu suatu tindakan yang dilakukan oleh guru untuk memperbaiki atau meningkatan kualitas pembelajaran di kelas. Hasil penelitian yang diperoleh menunjukkan bahwa proses pembelajaran IPA dengan menerapkan media grafis dalam proses belajar sangat sesuai dengan hasil belajar siswa yang tinggi, situasi belajar semakin menyenangkan dan diminati siswa. Nilai awal pada prasiklus yaitu 39 dengan nilai terendah 20 dan nilai tertinggi 60 , kemudian pada siklus I rata-rata nilai yang diperoleh siswa mengalami peningkatan yaitu 61 dengan nilai terendah 45 dan nilai tertinggi 85 dan bertambah meningkat pada siklus II dengan rata-rata nilai 69 dengan nilai terendah 45 dan nilai tertinggi 85 , kemudian pada siklus III semakin meningkat secara signifikan dengan rata-rata nilai 84 dengan nilai terendah 75 dan nilai tertinggi 95 . Hal ini menunjukkan kemajuan, dimana siswa telah mendapatkan hasil belajar yang meningkat dari prasiklus, siklus I sampai dengan siklus III.
\end{abstract}

Kata kunci: Efektivitas, Media Grafis, Hasil Belajar IPA.

\section{PENDAHULUAN}

Masalah pendidikan dan pengajaran merupakan masalah yang cukup kompleks di mana banyak faktor yang ikut mempengaruhinya. Salah satu faktor tersebut diantaranya adalah guru, dalam proses pembelajaran guru masih cenderung verbalisme dalam menyampaikan materi pelajaran. Dalam mengikuti proses pembelajaran kebanyakan siswa hanya mendengarkan ceramah guru, lalu mencatat materi yang ada di papan tulis meskipun tidak dimengerti, sehingga guru berfungsi sebagai sumber belajar dan memegang otoritas tertinggi keilmuan (teacher centered). Penggunaan metode konvensional tersebut menyebabkan siswa cenderung bergantung pada guru untuk mendapatkan mata pelajaran. Permasalahan pada pembelajaran konvensional dapat diatasi dengan penggunaan media pembelajaran yang inovatif. Pembelajaran yang inovatif merupakan pembelajaran yang mampu menarik perhatian siswa melalui pelibatan aktif siswa yang bersangkutan. Melalui pembelajaran yang inovatif diharapkan mampu meningkatkan kualitas peserta didik (Suparwoto, 2004: 128).

Kualitas peserta didik yang dihasilkan menunjukkan keberhasilan dalam proses belajar salah satunya dapat dilihat dari hasil belajar yang dicapai siswa. Hasil belajar merupakan apa yang diperoleh siswa setelah melakukan aktivitas belajar. Hasil belajar siswa mencakup aspek kognitif, afektif dan psikomotor. Peningkatan hasil belajar siswa dipengaruhi oleh beberapa faktor. Faktor yang mempengaruhi hasil belajar dapat digolongkan menjadi dua, yakni faktor internal dan faktor eksternal. Faktor internal 
adalah faktor yang berasal dari dalam individu itu sendiri, sedangkan faktor eksternal adalah faktor yang berasal dari luar individu (Supriyono, 2008).

Ilmu pengetahuan alam (IPA) berkaitan dengan cara mencari tahu tentang alam secara sistematis, sehingga IPA bukan hanya kumpulan pengetahuan berupa fakta-fakta, konsep-konsep, atau prinsip-prinsip saja tetapi juga merupakan suatu proses penemuan. Kendala dalam kegiatan belajar IPA adalah siswa masih menganggap bahwa materi pelajaran IPA merupakan materi yang membosankan dan banyak teorinya. Selain itu, banyak di antara siswa yang menganggap pelajaran IPA adalah sesuatu yang memusingkan. Menurut salah satu guru SMP di suatu sekolah Jakarta Timur, dalam proses pembelajaran di kelas masih banyak guru yang belum menggunakan berbagai macam variasi dalam mengajar, umumnya masih menggunakan metode konvensional, selain itu kurangnya motivasi dalam diri siswa untuk belajar dan memperhatikan guru ketika menerangkan materi pelajaran. Hal ini kemudian berdampak pada hasil belajar siswa yang kurang memuaskan, khususnya pada pelajaran IPA di kelas VII SMP yang hasil belajarnya masih dibawah nilai Kriteria Ketentuan Minimal (KKM) yaitu 75.

Keadaan tersebut perlu diperhatikan oleh seorang pendidik khususnya guru mata pelajaran IPA agar selalu berusaha untuk menciptakan inovasi dalam pembelajaran IPA sehingga hasil belajar siswanya mengalami peningkatan. Di antara inovasi tersebut salah satunya yaitu dengan menggunakan media pembelajaran yang tepat. Salah satu yang menjadi perhatian penulis adalah media grafis.

Media pembelajaran merupakan unsur yang amat penting dalam proses pembelajaran selain metode mengajar. Salah satu media diantaranya adalah multimedia, yang digunakan untuk menyajikan informasi dalam bentuk yang menyenangkan, menarik, mudah dimengerti, dan jelas. Informasi akan mudah dimengerti karena sebanyak mungkin indera, terutama telinga dan mata, digunakan untuk menyerap informasi itu (Hamalik, 2004). Demikian halnya pembelajaran sistem koordinasi biologi bervisi SETS. Guru sedapat mungkin membawa siswa ke arah pemikiran yang menyeluruh dan terpadu dengan mengaitkan antara materi biologi yang dipelajari dengan keberadaan serta implikasi materi tersebut dengan lingkungan, teknologi, dan masyarakat.

Media grafis merupakan media visual yang menyajikan fakta, ide atau gagasan melalui penyajian kata-kata, kalimat, angka-angka dan simbol atau gambar. Media grafis memiliki banyak jenis seperti grafik, diagram, bagan, sketsa, poster, papan flannel, papan buletin, kartun, gambar dan sebagainya. Ada beberapa media grafis yang telah diterapkan oleh guru akan tetapi dari beberapa media lain peneliti memilih media gambar untuk diterapkan dalam proses pembelajaran, karena gambar merupakan bahasa yang umum yang dapat dimengerti dan dinikmati dimana-mana. Gambar juga dapat memperjelas suatu masalah dalam bidang apa saja dan untuk usia berapa saja. Dengan penggunaan media tersebut akan lebih menarik perhatian, memperjelas sajian ide, dan mengilustrasikan fakta-fakta sehingga akan lebih meningkatkan daya serap siswa dalam memahami pesan-pesan pembelajaran. Dengan begitu, pengajaran yang serba verbalistik dalam proses pembelajaran di kelas akan berkurang dengan sendirinya, sehingga proses pembelajaran merupakan hubungan timbal balik antara seorang guru dengan siswanya di dalam kelas. Dalam pembelajaran guru hanya sebagai fasilitator dimana kegiatan belajar akan dititik beratkan pada keaktifan siswa (Colburn, 2010).

\section{TINJAUAN PUSTAKA}

Mata pelajaran IPA juga dapat dipandang sebagai program untuk menanamkan dan mengembangkan pengetahuan, keterampilan, sikap dan nilai ilmiah pada siswa serta rasa mencintai dan menghargai kebesaran Tuhan Yang Maha Esa. Pelajaran IPA tidak semata-mata memberi pengetahuan tentang berbagai gejala alam pada siswa, tetapi juga 
ikut membina kepribadian anak. Menurut Sudjana (dalam Rohwati, 2012: 76), "hasil belajar adalah suatu proses yang ditandai dengan adanya perubahan pada diri seseorang". Perubahan sebagai hasil dari proses belajar ditunjukkan dalam berbagai bentuk seperti perubahan sikap, tingkah laku serta perubahan aspek lain yang ada pada individu yang belajar.

Hasil belajar merupakan hal yang penting yang akan dijadikan tolak ukur keberhasilan siswa dalam belajar dan sejauh mana sistem pembelajaran yang diberikan guru berhasil atau tidak. Suatu proses belajar mengajar dikatakan berhasil apabila kompetensi dasar yang diinginkan tercapai. Untuk mengetahui tercapai tidaknya kompetensi tersebut guru mengadakan tes setelah menyajikan materi pembelajaran kepada siswa. Dari hasil tes ini diketahui sejauh mana keberhasilan siswa dalam belajar. Dalam proses belajar mengajar kehadiran media mempunyai arti yang cukup penting. Karena dalam kegiatan tersebut ketidakjelasan bahan yang disampaikan dapat dibantu dengan menghadirkan media sebagai perantara. Kerumitan bahan yang akan disampaikan kepada anak didik dapat disederhanakan dengan bantuan media, karena adanya media tersebut akan lebih meningkatkan daya serap siswa dalam memahami pesan-pesan pembelajaran. Di antara media pembelajaran media grafis adalah media yang paling umum dipakai.

Media grafis adalah seni atau ilmu menggambar, terutama diartikan untuk menggambar mekanik, juga diartikan sebagai penjelasan yang hidup, penjelasan yang kuat atau penyajian yang efektif (Sudjana dan Rifai dalam Safei, 2007). Media grafis termasuk media visual, sebagaimana halnya media yang lain media grafis berfungsi untuk menyalurkan pesan dari sumber ke penerima pesan, saluran yang dipakai menyangkut indera penglihatan, pesan yang akan disampaikan dituangkan ke dalam simbol-simbol komunikasi visual (Sadiman dkk., 2011). Simbol-simbol tersebut perlu dipahami benar artinya agar proses penyampaian pesan dapat berhasil dan efisien. Selain fungsi umum tersebut, secara khusus grafis biasanya berfungsi untuk menarik perhatian, memperjelas sajian ide dan mengilustrasikan fakta-fakta sehingga menarik dan mudah untuk diingat.

Pengertian yang sama juga dikemukakan oleh Sudjana dalam Safei (2008: 118) bahwa, "media grafis adalah media pembelajaran yang terdiri atas lambang-lambang, titik-titik dan simbol serta garis yang menghubungkan variabel yang satu dengan yang lainnya". Berdasarkan beberapa pengertian tersebut, dapat dikatakan bahwa media grafis dalam peranannya sebagai penyalur pesan dari pengirim kepada penerima pesan yang mengandalkan simbol-simbol atau garis-garis maupun gambar-gambar bahkan titik-titik yang bersifat visual dimana indera yang banyak diandalkan adalah penglihatan.

\section{Macam-macam Media Grafis}

Menurut Sadiman dkk. (2011) beberapa jenis media pembelajaran yang termasuk pada media grafis yaitu: a) Grafik, grafik adalah gambar sederhana yang menggunakan titik-titik, garis, atau gambar. Untuk melengkapinya seringkali simbolsimbol verbal digunakan. Fungsinya adalah menggambarkan data secara kuantitatif dan teliti, menerangkan perkembangan atau perbandingan sesuatu objek atau peristiwa yang saling berhubungan secara singkat dan jelas. b) Diagram, diagram adalah gambaran yang sederhana yang dirancang untuk menggambarkan hubungan timbal balik, yang biasanya disajikan melalui garis-garis simbol. Diagram biasanya menggambarkan struktur dari objeknya secara garis besar, menunjukkan hubungan yang ada antar komponennya, atau sifat-sifat proses yang ada disitu. c) Bagan, bagan seperti halnya media grafis yang lain yaitu termasuk media visual. Media bagan adalah suatu media pengajaran yang penyajiannya secara diagramatik dengan menggunakan lambing-lambang visual, untuk mendapatkan sejumlah informasi yang menunjukkan perkembangan ide, objek, lembaga, 
orang, keluarga ditinjau dari sudut waktu dan ruang, pesan yang disampaikan biasanya berupa ringkasan visual suatu proses, perkembangan atau hubungan-hubungan penting. Sebagai media yang baik, bagan haruslah dapat dimengerti siswa, sederhana dan lugas tidak rumit dan berbelit-belit serta dapat diganti pada waktu-waktu tertentu agar selain tetap termasa (up to date) juga tidak kehilangan daya tarik. d) Sketsa, sketsa adalah gambar yang sederhana atau draft kasar yang melukiskan bagian-bagian pokok dari suatu bentuk gambar. e) Poster, poster adalah sajian kombinasi visual yang jelas, menyolok, dan menarik dengan maksud untuk menarik perhatian orang yang lewat. Poster yang baik hendaknya sederhana, menyajikan satu ide dan untuk mencapai satu tujuan pokok, berwarna, slogannya ringkas, tulisannya jelas, motif dan desain bervariasi. Dan e) Gambar, gambar merupakan bahasa yang yang umum, yang dapat dimengerti dan dinikmati di mana-mana, oleh karena itu, pepatah Cina yang mengatakan bahwa sebuah gambar berbicara lebih banyak daripada seribu kata.

\section{METODE}

Jenis penelitian yang digunakan dalam penelitian ini adalah Penelitian Tindakan Kelas (PTK). Hal ini dikarenakan penelitiannya dilakukan pada kondisi yang alamiah (Sugiyono, 2013). Kondisi yang alamiah dapat diartikan bahwa peneliti bertugas memaparkan keadaan penelitian sesuai dengan data yang terdapat di lapangan, untuk mengetahui gambaran yang jelas mengenai peningkatan hasil belajar IPA dengan menggunakan media grafis di kelas VII SMP Negeri 209 Jakarta. Menurut Arikunto (2010), penelitian tindakan kelas (PTK) adalah suatu pencermatan terhadap kegiatan belajar berupa tindakan, yang sengaja dimunculkan dan terjadi di dalam sebuah kelas secara bersama. Tindakan tersebut berasal dari guru atau berupa arahan guru yang dilakukan oleh peserta didik.

Desain penelitian tindakan kelas menurut Kurt Lewin (dalam Sumadayo, 2013: 40) di dasarkan bahwa penelitian tindakan kelas terdiri dari empat komponen pokok yaitu perencanaan, tindakan, pengamatan (observasi) dan refleksi. Hubungan antara keempat komponen tersebut dipandang sebagai sebuah siklus atau kegiatan yang berulang. Siklus inilah sebetulnya yang menjadi salah satu ciri utama dari PTK, setelah satu siklus selesai barangkali guru menemukan masalah baru atau masalah lama yang belum dapat dipecahkan, dilanjutkan ke siklus kedua dengan langkahnya sama seperti pada siklus satu. Demikian, berdasarkan hasil tindakan siklus pertama guru akan kembali mengikuti langkah perencanaan, tindakan, observasi dan refleksi pada siklus kedua. Jika peneliti belum merasa puas, dapat melanjutkan ke siklus ketiga dengan cara dan tahapan yang sama seperti siklus sebelumnya. Bagi peneliti pengamat atau observer, siklus dihentikan apabila data yang dikumpulkan untuk penelitian sudah cukup dan telah mencapai indikator-indikator keberhasilan.

Populasi dalam penelitian ini adalah siswa kelas VII SMP Negeri 209 Jakarta, tahun ajaran 2014/2015 berjumlah tujuh kelas, yaitu VII A sampai dengan VII G, yang seluruhnya berjumlah 246 siswa. Populasi dalam penelitian ini merupakan subjek yang terlibat aktif dalam kegiatan belajar mengajar di SMP Negeri 209 Jakarta dan menjadi peserta didik dalam mata pelajaran ilmu pengetahuan alam (IPA). Dalam penelitian Tindakan kelas (PTK), peneliti menggunakan teknik sampling berupa purposive sampling. Disebut purposive sampling karena peneliti menentukan sampel yang akan digunakan dalam penelitian dengan pertimbangan tertentu. Sampel yang dipilih dianggap paling tahu dan dapat memberikan informasi yang maksimum sehingga akan memudahkan peneliti mengetahui objek yang diteliti (Sugiono, 2013), sehingga dari 34 siswa pada kelas VII F peneliti hanya mengambil 30 siswa untuk dijadikan sampel dalam 
penelitian, karena dikhawatirkan adanya ketidakhadiran satu atau lebih siswa pada saat pelaksanaan penelitian berlangsung.

\section{HASIL DAN PEMBAHASAN Prasiklus}

Sebelum melakukan penelitian, peneliti melakukan tes awal kepada siswa kelas VII F SMP Negeri 209 Jakarta untuk mengetahui sejauh mana kemampuan para siswa terhadap materi memahami saling ketergantungan dalam ekosistem. Diawali dengan ucapan salam kemudian dilanjutkan perkenalan dengan seluruh siswa, setelah itu peneliti menjelaskan tentang langkah-langkah proses belajar mengajar pada mata pelajaran IPA di kelas VII F. Kegiatan pembelajaran dilakukan selama dua jam pelajaran (90 menit). Setelah berkenalan guru memulai pelajaran dengan mengkondisikan siswa agar siap belajar, mengabsensi siswa dan mempersilahkan ketua memimpin doa. Setelah berdoa guru menjelaskan sekilas materi ekosistem tentang memahami saling ketergantungan ekosistem.

Pada saat menjelaskan, sebagian siswa memperhatikan penjelasan pelajaran dengan baik, namun masih ada siswa yang tidak memperhatikan penjelasan yang diberikan oleh guru. Setelah menjelaskan siswa dipersilahkan untuk mencatat. Setelah semua siswa menyelesaikan catatannya, peneliti membagikan lembaran kerja siswa berupa pilihan ganda. Siswa diminta mengerjakan dalam waktu 45 menit dan sisa waktunya digunakan untuk refleksi. Nilai rata-rata pada prasiklus adalah 39 dengan nilai tertinggi adalah 60 dan nilai terendah adalah 20. Jumlah siswa yang mengikuti tes adalah 30 siswa. Berikut disajikan nilai tes prasiklus.

Bedasarkan hasil pengamatan yang dilakukan selama prasiklus diperoleh analisis bahwa proses pembelajaran tidak berjalan dengan sempurna, masih ada beberapa kegiatan yang belum berjalan sebagaimana mestinya, siswa masih pasif. Kebanyakan siswa masih banyak yang melakukan kegitan seperti mengobrol temannya, tidur-tiduran dan malu untuk bertanya kepada guru atau tidak sama sekali. Berdasarkan hasil wawancara kepada guru, pembelajaran biasanya dilakukan dengan metode ceramah dan kelompok saja dan jarang menggunakan metode lain seperti media pembelajaran grafis karena keterbatasan waktu.

Berdasarkan uraian di atas, perlu adanya proses pembelajaran yang aktif dan kreatif dengan adanya interaksi aktif antara guru dengan siswa, siswa dengan siswa. Hal ini dapat mendorong siswa menjadi lebih aktif dan dapat menumbuhkan pemahaman siswa sehingga hasil belajarnya lebih efektif dan baik. Selain itu, aktivitas siswa akan diperkaya dengan media pembelajaran yang inovatif yaitu dengan media grafis.

\section{Siklus I}

Siklus I terdiri dari tiga kali pertemuan. Pertemuan pertama dan berlangsung selama dua jam pelajaran (90 menit) dan pertemuan ketiga berlangsung selama satu jam pelajaran (45 menit) untuk evaluasi, dengan berpedoman pada standar kompotensi mata pelajaran IPA, hasil belajar utama yang akan diperoleh adalah hasil belajar kognitif, namun hasil belajar dari segi afektif juga tetap diperhatikan. Metode yang digunakan adalah ceramah dan tanya jawab sedangkan media yang digunakan adalah papan tulis, video serta buku paket buku paket IPA untukn SMP/MTs Kelas VII dengan materi ekosistem. Tindakan yang dilakukan pada tahap ini merupakan perbaikan yang dilakukan berdasarkan hasil observasi dan hasil belajar siswa pada tahap prasiklus. Perbaikan dilakukan untuk memperbaiki proses pembelajaran agar menjadi lebih baik dibanding tahap prasiklus guna meningkatkan hasil belajar IPA pada siswa. 
Sebagai kegiatan awal guru mengkondisikan siswa agar siap belajar, mengabsensi siswa dan mempersilahkan ketua untuk memimpin doa, setelah itu guru menyampaikan tujuan pembelajaran. Kegatan inti guru menjelaskan tentang pengertian ekosistem, macam-macam ekosistem dan satuan makhluk hidup dalam ekosistem dengan metode ceramah, namun masih ada siswa yang mengobrol, sehingga suasana kelas menjadi sedikit ramai Guru bersama siswa melakukan tanya jawab yang mengarah pada materi yang diajarkan, kemudian guru memberikan kesempatan satu-persatu kepada siswa tersebut untuk menjelaskan jawabannya, karena bel waktu istirahat telah berbunyi, kemudian kegiatan pembelajaran diakhiri dengan guru memberitahu siswa agar membaca pokok bahasan selanjutnya di rumah.

Kegiatan selanjutnya guru menyampaikan tujuan pembelajaran lalu pada kegiatan inti guru membuka pelajaran dengan menampilkan video tentang ekosistem, siswa melakukan pengamatan, kemudian guru mengadakan tanya jawab yang mengarah pada materi yang diajarkan. Media tersebut diharapkan dapat membuat proses pembelajaran menjadi lebih mudah dipahami. Beberapa siswa mengajukan pertanyaan tentang hal-hal yang belum mereka pahami dan guru menjawab semua pertanyaan tersebut. Kegiatan pembelajaran di akhiri dengan guru dan siswa membuat rangkuman atau kesimpulan pembelajaran pada hari ini dan memberi pesan kepada siswa agar belajar lebih giat.

Pertemuan ketiga diadakan tes belajar siklus I. Guru dibantu observer membagikan tes belajar, karena proses pembelajaran hanya berlangsung selama satu jam pelajaran (45 menit) setelah tes belajar dibagikan, guru menginstruksikan agar mengerjakan sendiri-sendiri dan tidak banyak mengobrol. Guru dan observer memonitor jalannya tes belajar, mengingat waktu sudah hampir habis guru menginstruksikan kembali untuk meneliti jawaban dan menuliskan namanya agar tidak lupa sebelum dikumpulkan. Guru dibantu observer mengumpulkan jawaban siswa kemudian guru menutup kegiatan dengan mengucapkan salam.

Setelah guru melakukan tindakan pelaksanaan pembelajaran dengan media grafis dan dari data-data yang diperoleh yang kemudian dikumpulkan peneliti melakukan analisis dan refleksi kegiatan pelaksanaan tindakan tersebut. Pada siklus I sudah mengalami perubahan atau peningkatan dibandingkan pada saat prasikus, walaupun masih ada beberapa siswa yang belum mengalami perubahan. Hasil tersebut mencerminkan bahwa siklus I masih belum berjalan dengan sempurna. Masih banyak kegiatan yang belum berjalan sebagaimana mestinya. Oleh karena itu, penelitian ini harus dilanjutkan ke siklus selanjutnya untuk diadakan perbaikan.

\section{Siklus II}

Siklus II terdiri dari tiga kali pertemuan. Pertemuan pertama dan kedua berlangsung selama dua jam pelajaran (90 menit) dan pertemuan ketiga berlangsung selama satu jam pelajaran (45 menit) untuk evaluasi, dari hasil refleksi dan evaluasi pada siklus I diketahui bahwa penerapan media pembelajaran grafis masih kurang efektif karena guru masih mendominasi dan belum menunjukkan peningkatan hasil belajar yang signifikan. Oleh karena itu, peneliti kembali menyusun rencana pembelajaran untuk mengulang pembelajaran materi ekosistem pada pokok bahasan rantai makanan, jaringjaring makanan dan piramida makanan dan pola interaksi dalam ekosistem. Langkahlangkah penyusunan rencana pembelajaran seperti pada siklus I, yaitu menentukan tema dan penyusunan perencanaan pembelajaran. Hasil analisis terhadap siswa pada siklus I sebagian besar siswa masih mengalami kesulitan dalam memahami materi. Maka rancangan kegiatan pembelajaran menekankan pada pemahaman konsep dengan meningkatkan media grafis melalui pemilihan warna gambar yang menarik dan menampilkan media lebih besar agar lebih jelas untuk dilihat. 
Dalam kegiatan pembelajaran guru menerangkan pelajaran dengan menggunakan media pembelajaran grafis yang dibantu dengan power point dengan menampilkan materi ekosistem melalui video ekosistem, kemudian siswa disuruh melakukan pengamatan terhadap video yang ditampilkan. Proses pembelajaran juga diselingi dengan metode ceramah dan tanya jawab. Guru menyuruh siswa untuk melakukan pengamatan terhadap video yang di tampilkan. Kegiatan selanjutnya adalah guru mengadakan tanya jawab yang mengarah pada materi yang diajarkan. Agar suasana kelas tetap kondusif guru menunjuk salah satu siswa melalui buku absensi untuk menjawab pertanyaan yang telah disampaikan, kemudian pada kegiatan akhir guru dan siswa membuat kesimpulan atau rangkuman pembelajaran hari ini dan berpesan kepada siswa agar membaca pokok bahasan selanjutnya di rumah.

Pertemuan kedua pada siklus II, pokok bahasan yang diajarkan adalah arus energi dalam ruang lingkup ekosistem dan pola interaksi dalam ekosistem. Sebagai kegiatan awal guru mengkondisikan siswa agar siap belajar, mengabsensi siswa dan mempersilahkan ketua memimpin doa. Sebelum melanjutkan materi berikutnya, guru mengulang sedikit materi sebelumnya dengan melakukan tanya jawab di awal, kemudian guru menunjuk salah satu siswa melalui buku absensi siswa, ternyata setelah dilakukan tanya jawab sebagian siswa ada yang dapat menjawab dengan benar tetapi ada juga siswa yang tidak dapat menjawab pertanyaan dengan alasan lupa. Hal ini mungkin dikarenakan siswa tersebut pada proses pembelajaran kurang memperhatikan saat guru menerangkan.

Guru memvariasikan cara mengajar, pertama guru memberikan materi dengan cara menampilkan video yang dibantu dengan power point, lalu untuk pertemuan berikutnya guru menampilakan gambar agar siswa tidak bosan, kemudian guru menyuruh siswa untuk mengamati dan tiap siswa diberi kesempatan untuk menjelaskan jawabannya. Dalam pengeloaan waktu juga lebih baik. Hal ini terlihat pada proses evaluasi yang dilakukan pada akhir siklus II. Evaluasi dilakukan untuk mengetahui peningkatan hasil belajar siswa melalui instrumen tes berupa pilihan ganda sebanyak 20 butir soal.

\section{Siklus III}

Hasil refleksi terhadap pelaksanaan pembelajaran IPA pada siklus III, secara umum telah menunjukkn sedikit peningkatan dibanding pada siklus I, dimana guru dalam melaksanakan pembelajaran semakin lancar. Mereka lebih banyak memperhatikan dan mengemukakan pertanyaan-pertanyaan, mereka juga terlihat lebih senang terhadap penggunaan media grafis karena penjelasan guru tidak hanya ngomong saja melainkan dengan menampilkan video dan juga gambar, yang tentunya berpengaruh terhadap kemampuan dalam menyelesaikan soal-soal ulangan secara tertulis.

Pada siklus II proses pembelajaran cukup berjalan dengan efektif dan menyenangkan di bandingkan pada siklus I, hal ini terjadi karena guru melaksanakan pembelajaran melalui media grafis, tetapi hasil tersebut tidaklah sepenuhnya mencerminkan bahwa siklus II berjalan dengan sempurna. Masih ada beberapa kegiatan yang belum berjalan sebagaimana mestinya. Berdasarkan pada tabel di atas bahwa tes formatif yang dilaksanakan setelah pembelajaran siklus II, hasil penelitian menunjukkan bahwa sebanyak 17 siswa atau 57\% memperoleh nilai di bawah KKM, sedangkan sebanyak 13 siswa atau 43\% dari jumlah seluruh siswa telah mencapai KKM. Untuk itu maka tindakan pembelajaran akan dilanjutkan ke siklus berikutnya untuk diadakan perbaikan, dengan harapan semua hasil belajar IPA siswa dapat mencapai KKM.

Siklus III terdiri dari 3 kali pertemuan. Pertemuan pertama dan kedua berlangsung selama dua jam pelajaran (90 menit) dan pertemuan ketiga berlangsung selama satu jam pelajaran (45 menit) untuk evaluasi, dari hasil refleksi dan evaluasi pelaksanaan pada siklus II diketahui dengan media grafis untuk materi Ekosistem, peran 
dan interaksinya yang dilaksanakan pada siklus I dan II belum menunjukkan peningkatan hasil belajar yang signifikan. Jadi belum memenuhi indikator kinerja penelitian ini, oleh karena itu peneliti kembali menyusun rencana pembelajaran untuk mengulang pembelajaran materi IPA dengan kompetensi dasar keanekaragaman makhluk hidup dalam pelestarian ekosistem. Langkah-langkah penyusunan rencana pembelajaran seperti siklus II, yaitu menyusun perencanaan pembelajaran, berdasarkan indikator yang terpilih. Maka rancangan kegiatan pembelajaran menekankan pada pemahaman konsep yang dilakukan dengan media grafis melalui video motivasi di awal pelajaran, menampilkan gambar dengan warna menarik dan pembentukan kelompok agar mereka bisa saling berdiskusi.

Kegiatan selanjutnya adalah siswa membentuk kelompok, tiap kelompok terdiri dari 4- 5 orang, kelompok dibentuk oleh guru langsung berdasarkan urutan absensi kelas, kemudian guru memberikan langkah-langkah yang harus dilakukan. Kegiatan inti guru menjelaskan tentang materi keanekaragaman makhluk hidup dalam pelestarian ekosistem dengan media grafis melalui power point. Pada siklus III ini guru hanya menampilkan gambar saja tanpa adanya teks dengan tujuan agar memudahkan siswa dalam memahami materi, siswa melakukan pengamatan terhadap gambar yang ditampilkan kemudian guru memberikan kesempatan satu-persatu kepada siswa tersebut untuk menjelaskan jawabannya dengan bahasa sendiri. Beberapa siswa mengajukan pertanyaan tentang halhal yang belum mereka pahami dan guru menjawab semua pertanyaan tersebut, kemudian perwakilan dari masing-masing kelompok memperoleh penjelasan tentang tugas kelompok. Masing-masing kelompok berdiskusi dan menjelaskan tugas sesuai dengan lembar kerja yang diterima. Selesai mengerjakan lembar kerja siswa tersebut kemudian dikumpulkan. karena masih masih waktu 20 menit pada hari itu juga tugas tersebut dibahas, kemudian guru memberi penjelasan singkat sekaligus memberikan kesimpulan. Selain itu, guru menyampaikan kepada siswa untuk belajar lagi di rumah.

Peneliti dan observer secara berkolaborasi melaksanakan observasi terhadap pelaksanaan pembelajaran pada masing-masing pertemuan. Observasi ditujukan kepada kegiatan guru (peneliti) dalam melaksanakan pembelajaran, aktivitas dan sikap siswa dalam pembelajaran dan suasana kelas saat pembelajaran. Keseluruhan data yang diperoleh dalam kegiatan ini termasuk pencatatan hasil tes akan digunakan sebagai bahan dan masukan untuk menganalisis upaya meningkatkan hasil belajar IPA dalam diskusi. Saat kegiatan pembelajaran sebagian besar tampak sangat antusias dan lebih aktif dalam menjawab pertanyaan.

Pada siklus III guru hanya menampilkan gambar saja tanpa adanya teks dengan tujuan agar memudahkan siswa dalam memahami materi. Mereka lebih banyak memperhatikan dan mengemukakan pertanyaan-pertanyaan. Aktivitas siswa dalam proses belajar dengan media grafis sudah mengarah pada proses pembelajaran yang lebih baik. Siswa lebih bersemangat dalam menerima pelajaran serta minat dan perhatian siswa meningkat.

Hasil refleksi terhadap pelaksanaan pembelajaran IPA pada siklus III, secara umum telah menunjukkan perubahan yang signifikan, dimana guru dalam melaksanakan pembelajaran semakin luwes. Persentase hasil belajar siswa makin meningkat, yang tentunya berpengaruh terhadap kemampuan dalam menyelesaikan soal-soal dalam ulangan secara tertulis. Berdasarkan hasil tersebut bahwa tes formatif yang dilaksanakan setelah pembelajaran siklus III, hasil penelitian menunjukkan bahwa siswa telah mencapai KKM. Data hasil evaluasi siklus III yang diperoleh sebesar 100\% dengan nilai tertinggi 95 dan terendah 75.

\section{PENUTUP}




\section{Simpulan}

Berdasarkan data prasiklus, siklus I, II dan III dalam proses belajar yang dilakukan di SMP Negeri 209 Jakarta pada kelas VII F dengan menerapkan media grafis ternyata terbukti efektif untuk meningkatkan hasil belajar IPA. Bukti secara kuantitatif adalah perbandingan persentase peningkatan hasil belajar yang semula $0 \%$ dengan ratarata nilai 39 pada prasiklus sebelum media grafis digunakan, kemudian mengalami sedikit peningkatan $13,3 \%$ dengan rata-rata nilai 61 pada siklus I dan bertambah meningkat pada siklus II yaitu $43 \%$ dengan rata-rata nilai 69 , kemudian pada siklus III semakin meningkat secara signifikan menjadi $100 \%$ dengan rata-rata nilai 84 , sedangkan bukti kualitatifnya banyaknya siswa yang menyatakan senang terhadap penggunaan media grafis ini, siswa menjadi aktif dalam mengemukakan pendapat dan juga dalam menjawab pertanyaan serta tumbuh rasa minat dan motivasi untuk mendapat hasil belajar IPA yang lebih baik, konsentrasi siswa pada mata pelajaran dan suasana kelas menjadi hidup.

\section{Saran}

Penggunaan media grafis menjadikan proses pembelajaran berjalan dengan efektif dan menarik, khususnya pada mata pelajaran IPA ternyata terbukti meningkatkan hasil belajar siswa. Untuk itu hendaknya para guru lebih berpikir tentang metode pembelajaran yang diterapkan untuk mencapai kompetensi dasar apalagi pada mata pelajaran IPA yang bukan hanya berupa fakta-fakta, konsep-konsep atau prinsip-prinsip saja tetapi juga merupakan suatu proses penemuan. Jadi bukan kegiatan pembelajaran yang hanya mendengarkan kemudian siswa mencatat materi yang diterangkan oleh guru. Dengan demikian penggunaan media dalam proses pembelajaran hendaknya lebih ditingkatkan, salah satunya dengan pemilihan gambar yang sesuai, pemilihan warna yang tepat dan juga menarik, sehingga bisa meningkatkan minat siswa untuk belajar. Meskipun media pembelajaran harus kita sendiri (guru) yang membuatnya, dalam artian jangan terpaku pada fasilitas yang ada.

\section{DAFTAR PUSTAKA}

Arsyad, A. 2007. Media Pembelajaran Berbasis SETS. Jakarta: Grafindo Persada.

Asnawir. 2002. Media Pembelajaran. Jakarta: Ciputat Press.

Binadja, A. 2002. Hakekat dan tujuan pendidikan SETS dalam kontek kehidupan dan pendidikan yang ada. Makalah Seminar dan Lokakarya Nasional.

Colburn. 2010. An inquiry primer, science scope. Journal of Science Education, 22 (4): 42-44.

Hamalik. 2004. Kurikulum dan Pembelajaran. Jakarta: PT Bumi Aksara.

Kemmis \& Taggart. 1988. The Action Research Planner (Third Edition). Victoria: Deakin University Pres.

Sardiman, AM. 2005. Interaksi dan Motivasi Belajar Mengajar. Jakarta: PT Raja Grafindo Persada.

Sharan, S. 1980. Cooperative learning in small groups: recent methods and effects on achievement, attitudes, and ethnic relations. Review of educational Research, 50, $241-258$. [versi elektronik].

Suparwoto. 2004. Kemampuan Dasar Mengajar. Yogyakarta: FIP Universitas Negeri Yogyakarta.

Supriyono. 2008. Penilaian hasil Proses Belajar Mengajar. Bandung: PT Remaja Rosda Karya. 